\title{
Mast Cell Tryptase Stimulates the Synthesis of Type I Collagen in Human Lung Fibroblasts
}

\author{
Jennifer A. Cairns and Andrew F. Walls \\ Immunopharmacology Group, Southampton General Hospital, Southampton SO16 6YD, United Kingdom
}

\begin{abstract}
Mast cell activation is a characteristic feature of chronic inflammation, a condition that may lead to fibrosis as a result of increased collagen synthesis by fibroblasts. We have investigated the potential of tryptase, the major protease of human mast cells, to stimulate collagen synthesis in the human lung fibroblast cell line MRC-5. Tryptase was isolated from human lung tissue by ion-exchange and affinity chromatography. At concentrations of 18 and $36 \mathrm{mU} / \mathrm{ml}$, tryptase stimulated both an increase in cell numbers, and a fivefold increase in DNA synthesis as determined by methyl- $\left[{ }^{3} \mathrm{H}\right]$ thymidine incorporation. Similar concentrations of tryptase resulted in a 2.5 -fold increase in collagen synthesis as determined both by incorporation of $\left[{ }^{3} \mathrm{H}\right]$ proline into collagen, and by assay of hydroxyproline concentrations in the supernatants. There was also a twofold increase in collagenolytic activity in the culture medium after tryptase treatment, indicating that the increase in collagen synthesis was not a consequence of decreased collagenase production. All of these actions of tryptase were reduced in the presence of the protease inhibitors leupeptin and benzamidine hydrochloride, indicating a requirement for an active catalytic site. SDS-PAGE and autoradiographic analysis of the $\left[{ }^{3} \mathrm{H}\right]$ collagen produced by the cells revealed it to be predominantly type I collagen. Our findings suggest that the release of tryptase from activated mast cells may provide a signal for abnormal fibrosis in inflammatory disease. (J. Clin. Invest. 1997. 99:1313-1321.) Key words: tryptase - proliferation • fibrosis • collagen $\bullet$ fibroblast
\end{abstract}

\section{Introduction}

Fibrosis, a conspicuous feature of chronically inflamed tissue, is characterized by progressive and excessive accumulation of extracellular matrix collagen (1) as a consequence of increased proliferation of fibroblasts (the major mesenchymal cell responsible for the synthesis of interstitial collagen). A feature of lung tissue from patients with fibrotic lung disease is an increased number of mast cells, many of which are in a state of partial degranulation (2) located in close proximity to proliferating fibroblasts $(2,3)$. Consistent with this observation are the increased concentrations of tryptase and other mast cell prod-

Address correspondence to Dr. Jennifer A. Cairns, Immunopharmacology Group. Southampton General Hospital, Southampton SO16 6YD, UK. Phone: 44-1703-796152; FAX: 44-1703-704183.

Received for publication 29 July 1996 and accepted in revised form 7 January 1997.

J. Clin. Invest.

(C) The American Society for Clinical Investigation, Inc. 0021-9738/97/03/1313/09 \$2.00

Volume 99, Number 6, March 1997, 1313-1321 ucts in bronchoalveolar fluid collected from patients with fibrotic lung disease $(4,5)$. Such evidence points to a close interaction between mast cells and fibroblasts which may be pivotal in the pathogenesis not just of fibrotic lung disease, but of scleroderma, keloid formation, chronic graft versus host disease, and other fibrotic conditions $(6,7)$.

Long-term culture of rat peritoneal mast cells with mouse fibroblasts has been found to result in fibrogenesis (8), while the ingestion of extruded mast cell granules by fibroblasts can stimulate the secretion of collagenase $(9,10)$, suggesting that mast cell granule constituents may modulate connective tissue cell function. For example, the addition of histamine to cultured fibroblasts has been shown to stimulate proliferation (11) and collagen synthesis (12). Mast cells also contain substantial quantities of heparin proteoglycans within the granules. Heparin can contribute to the fibrotic process by binding to and preventing the inactivation of fibroblast growth factors $(\text { FGFs) })^{1}$ (13-15), or by facilitating binding of FGF to high-affinity receptors (13). In addition, binding to heparin sequesters FGFs into a reservoir from which they can subsequently be released by enzymatic degradation of the proteoglycan (16). Mast cells are becoming recognized also as important sources of inflammatory cytokines-including interleukins 1, 4 and 6, tumor necrosis factor, transforming growth factor $\beta$, and basic fibroblast growth factor (17) — which could confer roles in initiating and regulating processes of inflammation and fibrosis.

The most abundant product of human mast cells is the serine protease tryptase. Tryptase is a tetrameric serine protease with a molecular size of $134 \mathrm{kD}$, comprised of four monomers of $32-34 \mathrm{kD}$, each with one catalytic site (18). Its presence is restricted almost exclusively to mast cells, where tryptase exists within the secretory granules in a complex with heparin proteoglycan (19). Approximately $10 \mathrm{pg}$ of tryptase per cell has been detected in mast cells derived from lung, while skin-derived mast cells contain about $35 \mathrm{pg}$ tryptase per cell (20). The enzymatic activities of tryptase demonstrated include $(a)$ the degradation of calcitonin gene-related peptide and vasoactive intestinal peptide $(21,22),(b)$ inactivation of fibrinogen (23), (c) activation of prostromelysin (24) and urinary plasminogen activator $(25)$, and $(d)$ cleavage of gelatinase and fibronectin (26). In addition, tryptase can interact with a number of cell types, and has been shown to be mitogenic for fibroblasts (27), canine smooth muscle cells (28), and epithelial cells (29), to stimulate eosinophil chemotaxis (30), to induce interleukin- 8 release, and to modulate expression of intercellular adhesion molecule I (ICAM-1) on epithelial cells (29).

The ability of tryptase to stimulate fibroblast proliferation is consistent with this major mast cell product having a role in fibrosis. Despite mounting evidence that mast cells and their mediators can contribute to fibrosis by activating fibroblasts

1. Abbreviations used in this paper: BAPNA, $N$ - $\alpha$-benzoyl-DL-arginine- $p$-nitroanilide hydrochloride; FGF, fibroblast growth factor. 
and stimulating collagen production, however, the actions of tryptase on collagen synthesis have not been studied. We have examined further the potential role of this protease in modulating fibroblast behavior, and have investigated in particular the ability of tryptase to stimulate collagen production from lung fibroblasts. We report that tryptase can stimulate the synthesis of collagen by fibroblasts, and that the major species produced is type I collagen.

\section{Methods}

Reagents. $N$ - $\alpha$-benzoyl-DL-arginine $p$-nitroanilide hydrochloride (BAPNA), porcine heparin glycosaminoglycan, leupeptin, benzamidine hydrochloride, DEAE-52, DEAE-Sephacel, II heparin-agarose, and hydroxyproline were obtained from Sigma Chemical Co. (Poole, UK). L- $\left[2,3-{ }^{3} \mathrm{H}\right]$ proline and $N$-[propionate-2,3- $\left.{ }^{3} \mathrm{H}\right]$ collagen (Rat I) were from Dupont NEN (Stevenage, UK), and collagenase (CLSPA grade) and trypsin were purchased from Worthington Biochemical Corp. (Freehold, NJ). Methyl- $\left[{ }^{3} \mathrm{H}\right]$ thymidine, Hyperfilm MP, and the autoradiography enhancing reagent Amplify were from Amersham International (Little Chalfont, UK). Recombinant human transforming growth factor $\beta$ (TGF- $\beta$ ) was purchased from $R$ and D Systems (Abingdon, UK). A neutralizing antibody to TGF- $\beta$ was purchased from Promega Ltd. (Southampton, UK), and a polyclonal antibody specific to collagen I from Euro-Path Ltd. (Bude, UK). Endotoxin in the tryptase preparations was assayed with the Toxicolor System (Seikagaku Corp., Tokyo, Japan). Protein was assayed with the Coomassie protein assay reagent (Pierce and Warriner Ltd., Chester, UK). All other reagents were of analytical grade, and were obtained from BDH (Poole, UK).

Cell culture. The MRC-5 fibroblast cell line, derived from human lung tissue, was obtained from the European Collection of Animal Cell Cultures (ECACC) (Porton Down, Salisbury, UK). The cells were grown in Minimum Essential Medium (MEM) (GIBCO BRL, Paisley, UK), supplemented with $10 \%$ fetal calf serum (GIBCO BRL), $100 \mathrm{U} / \mathrm{ml}$ penicillin, and $100 \mu \mathrm{g} / \mathrm{ml}$ streptomycin (Sigma). Cells were maintained at $37^{\circ} \mathrm{C}$ in a humidified atmosphere of $95 \%$ air and $5 \%$ $\mathrm{CO}_{2}$, and were used routinely between passages 24 and 32 (equivalent to population doublings) as aging fibroblasts in culture have a reduced capacity for collagen synthesis (31).

Purification and characterization of tryptase. Lung tissue collected post-mortem was used as the source of mast cell tryptase. The tissue was chopped finely, and tryptase was purified from the crude extract by means of ion-exchange chromatography with DEAE-Sephacel (32) and heparin agarose chromatography, as described previously (29). The purity of the tryptase samples was determined by silver staining after SDS-PAGE on $10 \%$ reducing gels (according to the method of Laemmli) (33), and the identity of the purified protein was confirmed by immunoblotting with the AA5 anti-tryptase antibody (34). Endotoxin levels in the tryptase preparations were less than $15 \mathrm{pg} / 200 \mu \mathrm{g}$ tryptase protein.

Assay for tryptase. Tryptase activity was assayed using the peptide substrate BAPNA. $10 \mu \mathrm{l}$ of enzyme was added to $90 \mu \mathrm{l}$ of $20 \mathrm{mM}$ Tris buffer ( $\mathrm{pH}$ 8.0) containing $1 \mathrm{M}$ glycerol and $7.77 \mathrm{mM}$ BAPNA. Absorbance was measured at $410 \mathrm{~nm}$, and tryptase activity was expressed in milliunits $(\mathrm{mU})$ per $\mathrm{ml}$ where $1 \mathrm{U}$ represents that required to hydrolyze $1 \mu \mathrm{mol}$ of substrate per min at $25^{\circ} \mathrm{C}$. The specific activity of the tryptase preparations used in this study ranged from 1.8 to $2.6 \mathrm{U} / \mu \mathrm{g}$.

Cell proliferation assay. Confluent fibroblasts were detached from culture flasks with a nonenzymatic cell dissociating solution (Sigma) and seeded into a 96-well microtiter plate at a density of $10^{5}$ cells per $\mathrm{ml}$ in MEM containing 10\% FCS. At confluence, the medium was replaced with serum-free (SF) medium consisting of MEM supplemented with $5 \mu \mathrm{g} / \mathrm{ml}$ bovine pancreas insulin, $5 \mu \mathrm{g} / \mathrm{ml}$ transferrin, and $5 \mathrm{ng} / \mathrm{ml}$ sodium selenite. After $24 \mathrm{~h}$ of serum deprivation, purified tryptase was added following its dialysis in the presence of heparin (1: 1 ; wt/wt; to stabilize enzymatic activity) (19) for $24 \mathrm{~h}$ at $4^{\circ} \mathrm{C}$ against phosphate-buffered saline (PBS). In experiments with protease inhibitors, tryptase with added heparin was incubated in the presence or absence of leupeptin or benzamidine hydrochloride for $1 \mathrm{~h}$ at $4^{\circ} \mathrm{C}$, after which the BAPNA cleaving activity of tryptase was assayed to determine the percentage of inhibition achieved. Control tryptase samples to which no inhibitor was added were incubated under the same conditions. The inhibitors were used at concentrations which in preliminary experiments had been shown to be nontoxic to the fibroblasts, and without effect on thymidine incorporation. After the various additions were made, the cells were incubated at $37^{\circ} \mathrm{C}$ for $32 \mathrm{~h}$ with the addition of $1 \mu \mathrm{Ci}$ of methyl-[ $\left.{ }^{3} \mathrm{H}\right]$ thymidine per well for the last $8 \mathrm{~h}$ to measure DNA synthesis. The cells were harvested and counted in scintillant. In addition, fibroblasts were seeded into 24well plates and incubated with two optimal doses of tryptase for $72 \mathrm{~h}$, and total cell number was determined by counting in a Neubauer hemocytometer (Fisher Scientific, Loughborough, UK) after staining with Trypan Blue.

Collagen assay. Collagen was assayed by measuring the incorporation of $\left[{ }^{3} \mathrm{H}\right]$ proline into collagen as described previously (35). Fibroblasts were plated at a density of $10^{5}$ per $\mathrm{ml}$ into 96-well microtiter plates, and grown to confluence in MEM (proline- and hydroxyproline-free) with $10 \%$ FCS and antibiotics. Confluent cells were then serum-starved for $48 \mathrm{~h}$ before the various additions were made. Purified tryptase with heparin (1:1, wt/wt) was dialyzed against MEM and used in the following studies. The time course of collagen production was determined by incubating the cells with $25 \mathrm{mU} / \mathrm{ml}$ of tryptase (with heparin) or with medium alone in the presence of $1 \mu \mathrm{Ci}$ of $\left[{ }^{3} \mathrm{H}\right]$ proline for $3,6,24$, and $48 \mathrm{~h}$. Total protein synthesis (both collagenous and non-collagenous) was determined by precipitating all the proteins in $100 \mu \mathrm{l}$ cell supernatant onto glass fiber filters and counting in a scintillant. Noncollagenous proteins were assayed in a second $100-\mu \mathrm{l}$ aliquot of the same supernatant after digestion with $40 \mu \mathrm{g}$ of purified bacterial collagenase for $2 \mathrm{~h}$ at $37^{\circ} \mathrm{C}$, as described by $\mathrm{Pe}-$ terkofsky and Diegelman (36). The precipitated collagenase-resistant proteins were defined as noncollagenous. A preliminary experiment had shown that digestion of collagenous proteins in fibroblast supernatants with this concentration of collagenase was essentially complete after $2 \mathrm{~h}$ (data not shown). The difference between total and noncollagenous protein counts was taken to reflect the amount of collagen synthesized. As a control, supernatant samples were incubated for the same period with purified trypsin (Worthington) to check for specificity of digestion by collagenase (data not shown). In subsequent experiments, fibroblasts were incubated for $48 \mathrm{~h}$ either with medium alone or with purified tryptase (with heparin) to determine the dose response to tryptase. Levels of cell-associated collagen were assayed in the cell monolayer as described above. Cells were rinsed two times with PBS, trypsinized, and lysed in $200 \mu \mathrm{l}$ of cold lysis buffer $(20 \mathrm{mM}$ Tris $\mathrm{HCl}$, pH 7.4, containing $150 \mathrm{mM} \mathrm{NaCl}, 1 \mathrm{mM}$ $\mathrm{MgCl}_{2}, 0.1 \mathrm{mM} \mathrm{ZnCl} 2,1 \mathrm{mM}$ EGTA, $1 \mathrm{mM}$ PMSF, $1 \mathrm{mg} / \mathrm{ml}$ leupeptin, $5 \mathrm{mM}$ benzamidine hydrochloride, and $1 \%$ Nonidet P-40).

To investigate if the action of tryptase was mediated via its catalytic site, cells were incubated with either purified tryptase (with heparin), or with tryptase (heparin) that had been preincubated with leupeptin or benzamidine hydrochloride as described above. As controls, collagen synthesis was assayed in supernatants from fibroblasts incubated with leupeptin or benzamidine hydrochloride alone, or with various concentrations of transforming growth factor $\beta$ (TGF- $\beta$ ) and heparin. Since TGF- $\beta$ is a potent stimulator of collagen synthesis in fibroblasts (1) and fibroblasts are known to release this cytokine, it was necessary to determine if tryptase-induced collagen synthesis may be mediated via enhanced TGF- $\beta$ release. An experiment was conducted in which cells were incubated with tryptase (with heparin) in the presence of either a neutralizing TGF- $\beta$ antibody or an irrelevant rabbit antibody. In addition, cells were incubated with antibody alone (with heparin) or with the irrelevant rabbit antibody at the same concentrations. Towards the latter part of this study, purified preparations of the monoclonal antibody to tryptase (AA5) became available in sufficient quantities to allow immunoaffinity purification 
of tryptase. An additional experiment using immunoaffinity purified tryptase was conducted to confirm the effect of tryptase on collagen synthesis.

Hydroxyproline assay. The collagen content of supernatants and cell monolayers from fibroblast cultures was assayed by spectrophotometric determination of hydroxyproline concentration according to the method of Juva and Prockop (37), incorporating some modifications described by Clark (38). Confluent fibroblast cultures were incubated with serum-free medium alone (control) or with tryptase (with heparin) in the presence or absence of inhibitors. The effect of heparin and TGF- $\beta$ on the hydroxyproline content of cell supernatants was also investigated. After a 48-h incubation, the cells were trypsinized, centrifuged, and the supernatants were assayed spectrophotometrically for hydroxyproline.

Characterization of collagen type. Analysis of the collagen type synthesized by fibroblasts in response to tryptase was carried out using anion exchange chromatography, a procedure which has been shown to separate procollagen type I from type III (39), according to the method of Phan, Varani and Smith (40). The focus was on type I and type III collagens, as they represent $80 \%$ and $20 \%$, respectively, of the total collagen synthesized by lung fibroblasts, and are the predominant connective tissue elements altered in fibrotic disorders (41). Confluent fibroblasts were incubated with either serum-free medium alone or with tryptase (with heparin) in the presence of $5 \mu \mathrm{Ci} /$ $\mathrm{ml}\left[{ }^{3} \mathrm{H}\right]$ proline for $52 \mathrm{~h}$. Two flasks of cells were used for each treatment, and the supernatant from each was harvested, pooled, and retained on ice while $1 \mathrm{mg} / \mathrm{ml}$ leupeptin, $0.5 \mathrm{mM}$ PMSF, $5 \mathrm{mM}$ EDTA, and $2.5 \mathrm{mM}$ NEM were added. The procollagens were precipitated at $4^{\circ} \mathrm{C}$ with $20 \%$ saturated ammonium sulphate for $24 \mathrm{~h}$, and the suspension was centrifuged at $48,000 \mathrm{~g}$ for $1 \mathrm{~h}$. The precipitate was resuspended in $25 \mathrm{mM}$ Tris $\mathrm{HCl}$ ( $\mathrm{pH} 7.5$ ), 1 mM EDTA, and $2 \mathrm{M}$ urea. The sample was applied onto a column of DEAE 52 that had been equilibrated in the same buffer, and procollagens were eluted according to the method of Clark (38) using a linear gradient of $0-0.22 \mathrm{M} \mathrm{NaCl}$ in $2 \mathrm{M}$ urea and $25 \mathrm{mM}$ Tris $\mathrm{HCl}, \mathrm{pH} 7.5$. Fractions of $5 \mathrm{ml}$ were collected and counted in a scintillant. Aliquots from peak fractions with high counts were assayed for collagen as described above.

Pooled fractions from the two major peaks eluted from the DE52 column were treated as previously described (40), lyophilized, resuspended in SDS sample buffer, and analyzed by SDS-PAGE with $7.5 \%$ slab gels according to the procedure of Neville (42) (with some modifications) (43). The gel was fixed, impregnated with Amplify, dried, exposed to Hyperfilm-MP for $10 \mathrm{~d}$, and developed using a commercial x-ray film developer.

Collagenase assay. Collagenase production and/or release from fibroblast cultures was assayed using ${ }^{3} \mathrm{H}$-rat tail tendon type I collagen as substrate according to the protocol outlined in the Collagenase Assay System (New England Nuclear, Boston, MA). Supernatants from control and tryptase-treated cultures were concentrated tenfold, incubated with the radiolabeled substrate for $3 \mathrm{~h}$ at $21^{\circ} \mathrm{C}$, centrifuged, and an aliquot was removed for counting. The collagenolytic activity was expressed as the percentage of substrate digested with reference to a standard curve using purified bacterial collagenase $(0-10 \mu \mathrm{g} / \mathrm{ml})$.

\section{Results}

Cell proliferation. An increase of up to fivefold in DNA synthesis was observed after incubation of quiescent cells for $36 \mathrm{~h}$ with tryptase (Fig. $1 \mathrm{~A}$ ). The increase in DNA synthesis at 18 and $36 \mathrm{mU} / \mathrm{ml}$ tryptase was accompanied by cell division after incubating cells with tryptase for a total of $72 \mathrm{~h}$ (Table I). At these concentrations of tryptase, the fibroblast monolayer remained intact when examined by phase contrast microscopy, and was indistinguishable from cells which had not been exposed to tryptase, suggesting that the increase in cell growth was not a nonspecific effect of tryptase resulting from cell de-

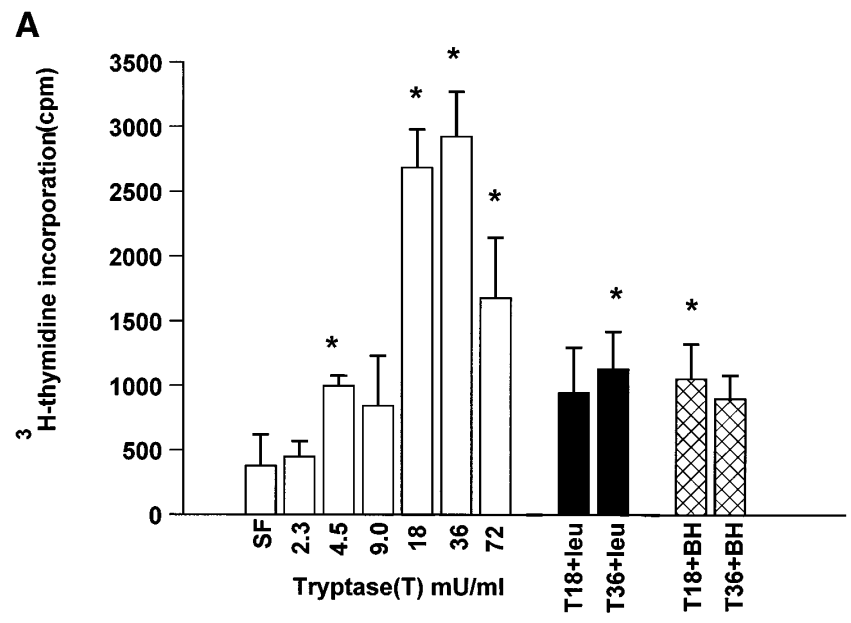

B

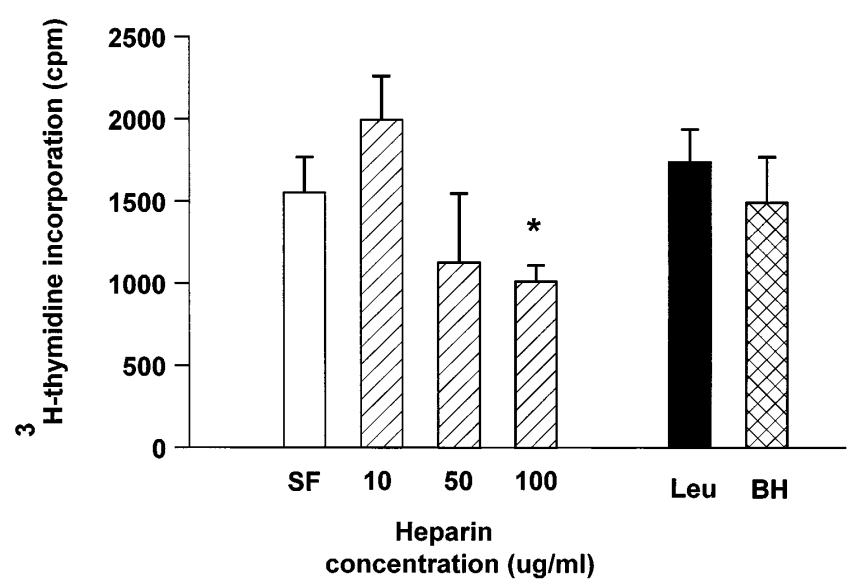

Figure 1. (A) Mitogenic response of fibroblasts to tryptase. Purified tryptase was incubated with quiescent cells in the presence of heparin $(1: 1, \mathrm{wt} / \mathrm{wt})$. Cells were incubated also with either 18 or $36 \mathrm{mU} / \mathrm{ml}$ tryptase in the presence of $50 \mu \mathrm{g} / \mathrm{ml}$ leupeptin (leu) or $50 \mu \mathrm{M}$ benzamidine hydrochloride $(B H)$. $(B)$ The effect of heparin and protease inhibitors $(50 \mu \mathrm{g} / \mathrm{ml}$ leupeptin or $50 \mu \mathrm{M}$ benzamidine hydrochloride) alone on cell proliferation. Values shown are means \pm SEM from three or four experiments. $* P<0.05$ compared with serum-free (SF) controls.

tachment and consequent release from contact inhibition. At the end of the labeling period, cell viability estimated by Trypan Blue exclusion was more than $90 \%$. Stimulation of $\left[{ }^{3} \mathrm{H}\right]$ thymidine incorporation by tryptase appeared to be reduced at $72 \mathrm{mU} / \mathrm{ml}$ compared to that seen at 18 and $36 \mathrm{mU} / \mathrm{ml}$. Again, this was not due to a cytotoxic effect as viability was still more than $90 \%$. However, when the cells were exposed to tryptase in excess of $150 \mathrm{mU} / \mathrm{ml}$, cell viability decreased to less than $70 \%$ with the cells lifting off from the monolayer (data not shown).

Preincubation of tryptase with either leupeptin or benzamidine hydrochloride reduced $\left[{ }^{3} \mathrm{H}\right]$ thymidine incorporation in fibroblasts (Fig. $1 \mathrm{~A}$ ), suggesting dependency on an active catalytic site. Using the same concentrations of protease inhibitors, the activity of tryptase $(18$ and $36 \mathrm{mU} / \mathrm{ml})$ towards the substrate BAPNA was inhibited by $90 \%$ in the case of leupeptin, and by $75 \%$ for benzamidine hydrochloride. Leupeptin and 
Table I. Effect of Tryptase Treatment on Cell Numbers

\begin{tabular}{lc}
\hline \multicolumn{1}{c}{ Treatment } & Cell number $\left(\times 10^{5}\right) /$ well \\
\hline Untreated controls & $6.9 \pm 2.4$ \\
Tryptase $(18 \mathrm{mU} / \mathrm{ml})$ & $7.7 \pm 0.9$ \\
Tryptase $(36 \mathrm{mU} / \mathrm{ml})$ & $11.9 \pm 1.1^{*}$ \\
Tryptase $(72 \mathrm{mU} / \mathrm{ml})$ & $9.9 \pm 3.5$ \\
$10 \%$ FCS & $13.8 \pm 0.8^{*}$
\end{tabular}

Fibroblasts were treated with $10 \%$ FCS or with tryptase (in the presence of heparin) for $72 \mathrm{~h}$. Cells were then detached and counted in a Neubauer hemocytometer. Means \pm SEM are shown from three individual experiments. ${ }^{*} P<0.05$ compared to untreated controls.

benzamidine hydrochloride alone at the concentrations used did not significantly affect $\left[{ }^{3} \mathrm{H}\right]$ thymidine incorporation in fibroblasts (Fig. $1 \mathrm{~B}$ ). Since all the tryptase preparations used in this study contained heparin in a 1:1 ratio (wt/wt) in order to maintain enzymatic activity, the effect of heparin alone on cell proliferation was assessed. Heparin at the concentrations employed had no significant effect on $\left[{ }^{3} \mathrm{H}\right]$ thymidine incorporation, although there was a tendency for inhibition at high concentrations of heparin (Fig. $1 B$ ).

Time course of collagen secretion. In fibroblasts exposed to $25 \mathrm{mU} / \mathrm{ml}$ tryptase, there was a threefold increase in collagen synthesis after $24 \mathrm{~h}$, and a fivefold increase after $48 \mathrm{~h}$ compared to untreated controls (Fig. 2). Cells not exposed to tryptase showed a low level of collagen synthesis with only a small increase over the same incubation period. The response was linear, and $48 \mathrm{~h}$ was the time point selected for further studies.

$\left[{ }^{3} \mathrm{H}\right]$ proline incorporation. A 2.5 -fold increase in collagen synthesis determined by the incorporation of $\left[{ }^{3} \mathrm{H}\right]$ proline was detected in fibroblast supernatants following incubation with tryptase (Fig. $3 A$ ). Leupeptin and benzamidine hydrochloride reduced the ability of tryptase to stimulate collagen synthesis. As was the case with the cell proliferation study, the response appeared to be reduced at $120 \mathrm{mU} / \mathrm{ml}$ tryptase, although no

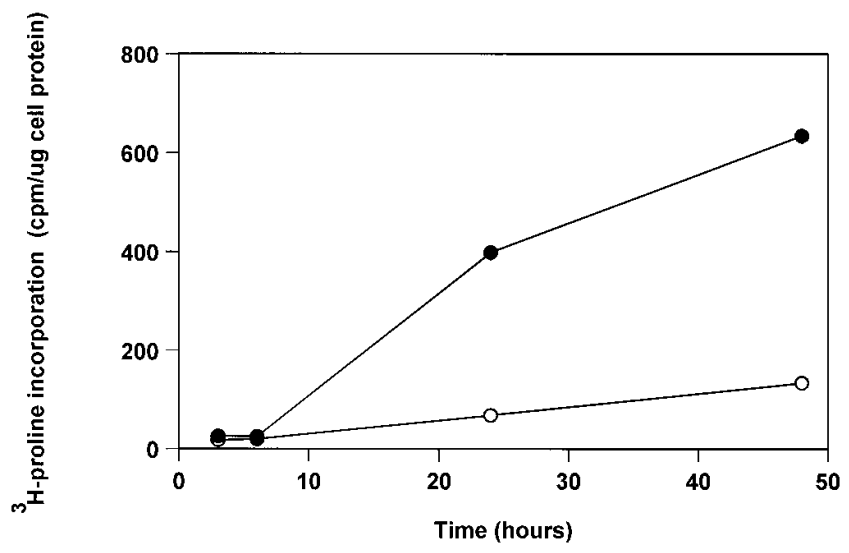

Figure 2. Time course of collagen secretion into cell culture supernatants. Fibroblasts were incubated either with medium alone $(\bigcirc)$ or with $25 \mathrm{mU} / \mathrm{ml}$ tryptase (with heparin) (๑) in the presence of $\left[{ }^{3} \mathrm{H}\right]$ proline. Collagen synthesis was determined from the incorporation of $\left[{ }^{3} \mathrm{H}\right]$ proline from triplicate wells of two separate experiments.
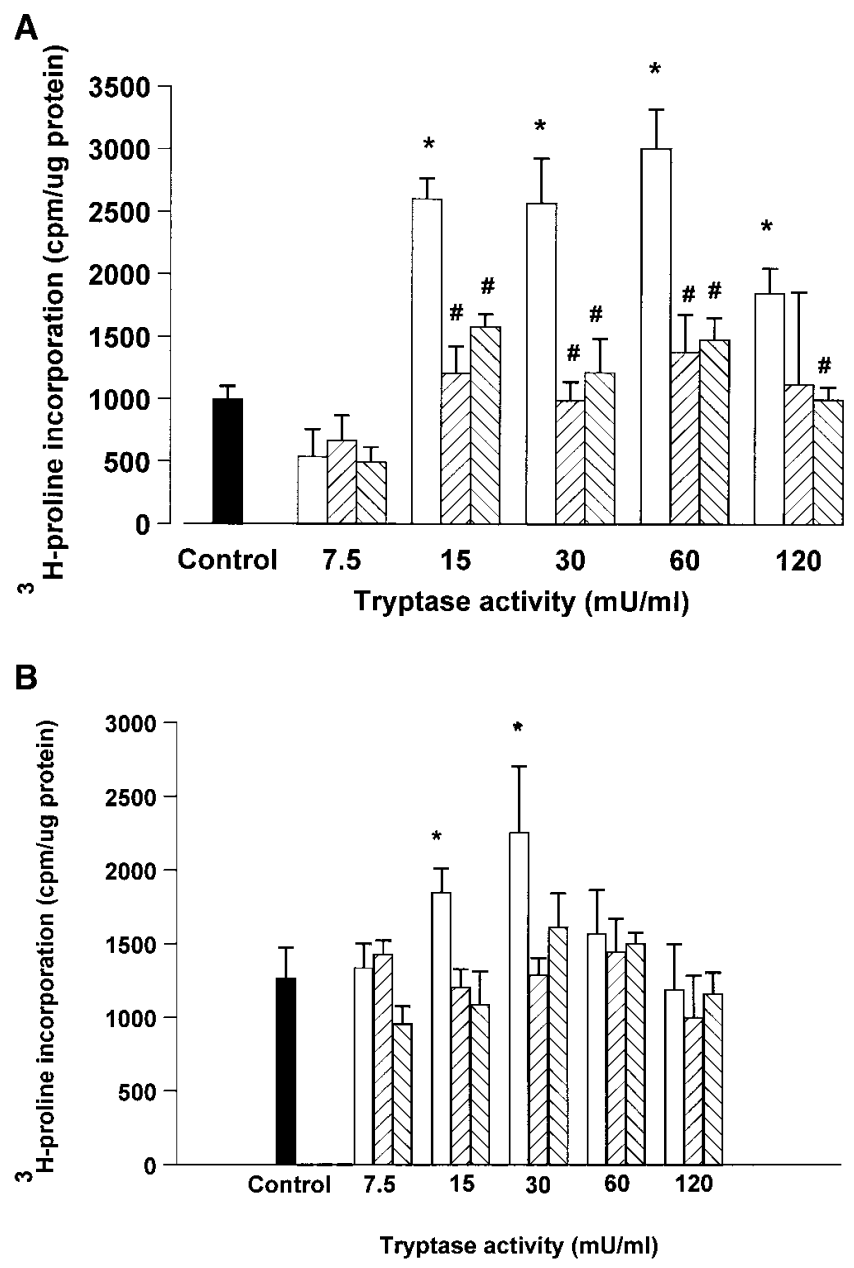

Figure 3. (A) Collagen synthesis (soluble) in fibroblasts incubated with medium alone (control) and with tryptase (with heparin) in the absence $(\square)$ or presence of $50 \mu \mathrm{g} / \mathrm{ml}$ leupeptin $(\square)$ or $50 \mu \mathrm{M}$ benzamidine hydrochloride $(\mathbb{\mathbb { N }})$ in five separate experiments. $(B)$ Collagen synthesis (cell-associated collagen) in fibroblasts treated in the same way as in $(A)$ in four separate experiments. Values shown are means \pm SEM. ${ }^{*} P<0.05$ compared with untreated controls. ${ }^{\#} P<0.05$ compared with non-inhibited tryptase at each concentration.

cytotoxic effects were evident, and the cell monolayer appeared intact as visualized under the microscope. Since not all the collagen synthesized is released into the supernatant, and a proportion may remain cell-associated, the cell monolayer was assayed for collagen synthesis in a similar manner, and the data was presented in Fig. 3 B. Very little collagen remained cell-associated, indicating that almost all the collagen synthesized by fibroblasts had been released into the supernatant. A small increase in proline incorporation was noted in lysates from cells incubated with 15 and $30 \mathrm{mU} / \mathrm{ml}$ tryptase, although the increase observed at $30 \mathrm{mU} / \mathrm{ml}$ was not reduced in the presence of benzamidine hydrochloride. It is possible that this amount may represent residual collagen associating nonspecifically with the cell surface. Leupeptin and benzamidine hydrochloride alone at the concentrations employed, and heparin at 10,50 , and $100 \mu \mathrm{g} / \mathrm{ml}$, did not have any significant effects on collagen synthesis (data not shown).

Under the same conditions, 1 and $10 \mathrm{ng} / \mathrm{ml}$ TGF- $\beta$ stimulated a 3.5-fold increase in collagen synthesis in fibroblasts, while 

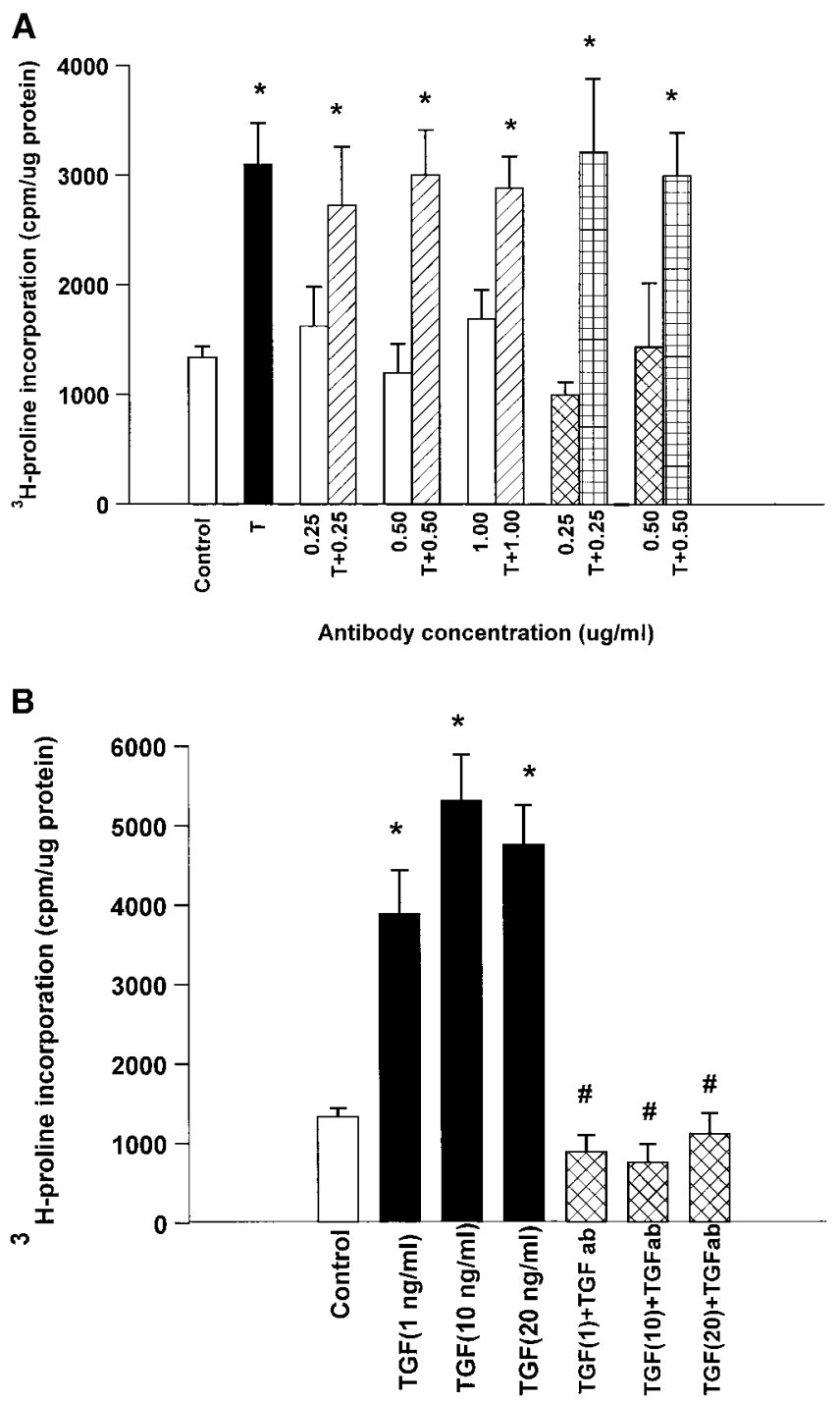

Figure 4. (A) Effect of a neutralizing antibody against TGF- $\beta$ on tryptase-induced collagen synthesis. Fibroblasts were incubated with $25 \mathrm{mU} / \mathrm{ml}$ tryptase $(T)$ with heparin $(\boldsymbol{\square})$, with $25 \mathrm{mU} / \mathrm{ml}$ tryptase (with heparin) in the presence of a neutralizing antibody (Ab) to TGF- $\beta(\square)$, or with antibody (with heparin) alone at the same concentrations $(\square)$. Cells were also incubated with an irrelevant antibody (plus heparin) either alone (国) or in the presence of $25 \mathrm{mU} / \mathrm{ml}$ tryptase (with heparin) $(\boxplus)$. ( $B$ ) Effect of a neutralizing antibody on TGF- $\beta$-induced collagen synthesis. Cells were incubated with TGF- $\beta$ alone or together with $10 \mu \mathrm{g} / \mathrm{ml}$ of the neutralizing antibody. Values are means \pm SEM from three experiments. $* P<0.05$ compared with untreated controls, ${ }^{\#} P<0.05$ compared with TGF- $\beta$ alone.

a 5-fold increase was found at $20 \mathrm{ng} / \mathrm{ml} \mathrm{TGF-} \beta$ (Fig. $4 A$ ). The concentration of tryptase required to stimulate collagen synthesis by 2.5 -fold was between 9.2 and $18.4 \mathrm{nM}$. When collagen assays were performed on cell supernatants after incubating cells with $25 \mathrm{mU} / \mathrm{ml}$ tryptase in the presence of a neutralizing antibody to TGF- $\beta$, no significant change in tryptase-stimulated collagen synthesis was observed, suggesting that the effect of tryptase on collagen synthesis was not mediated via increased TGF- $\beta$ release (Fig. $4 A$ ). There was no significant effect when cells were incubated with each of the three con-

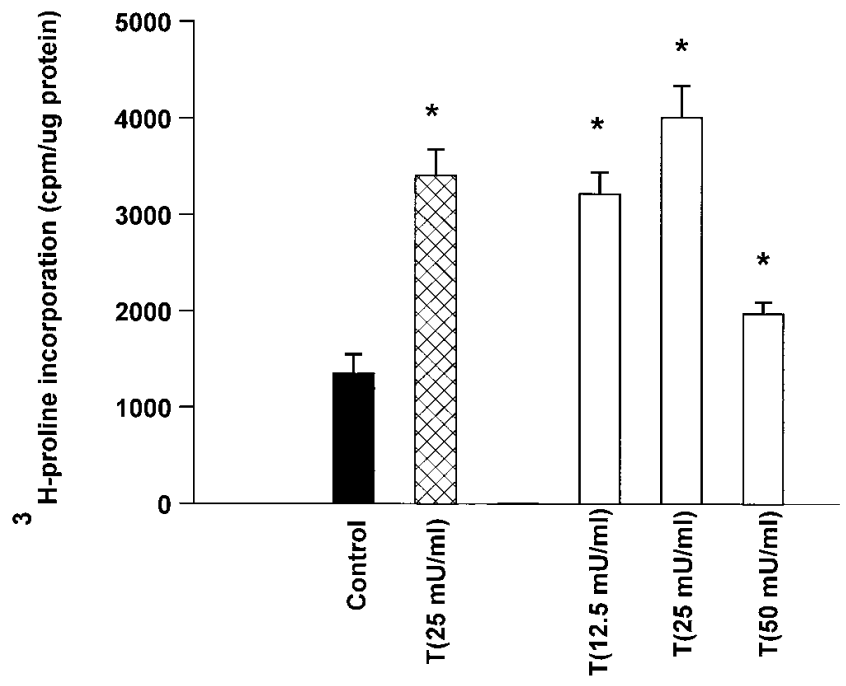

Figure 5. Effect of immunoaffinity purified tryptase on collagen synthesis. Fibroblasts were incubated with immunoaffinity purified tryptase with heparin (open bars), or with tryptase purified by ionexchange and heparin agarose (hatched bar) chromatography. Values are means \pm SEM for three experiments performed in triplicate. ${ }^{*} P<$ 0.05 compared with controls.

centrations of TGF- $\beta$ antibody in the presence of $10 \mu \mathrm{g} / \mathrm{ml}$ heparin. In another control experiment, the cells incubated with an irrelevant antibody in the absence or presence of $25 \mathrm{mU} / \mathrm{ml}$ tryptase showed no significant effect on collagen synthesis (Fig. 4 B). Collagen synthesis, however, was reduced when cells were incubated with TGF- $\beta$ in the presence of the neutralizing antibody against TGF- $\beta$. Tryptase purified by an immunoaffinity procedure with antitryptase monoclonal antibody AA5 stimulated collagen synthesis to a similar extent (Fig. 5) as that found using tryptase that had been purified by DEAEand heparin-agarose chromatography (Fig. $3 A$ ).

Table II. Hydroxyproline Content of Supernatants from Untreated Cells or from Cells Treated With Tryptase (With Heparin) in the Presence or Absence of $50 \mu \mathrm{g} / \mathrm{ml}$ Leupeptin, and the Effect of TGF- $\beta$ and of Heparin

\begin{tabular}{lc}
\hline \multicolumn{1}{c}{ Treatment } & Hydroxyproline concentration \\
\hline & $($ mmol/liter $)$ for $10^{6}$ cells \\
Untreated controls & $36.9 \pm 3.3$ \\
Tryptase $(\mathrm{T})(15 \mathrm{mU} / \mathrm{ml})$ & $52.1 \pm 5.2^{*}$ \\
Tryptase $(\mathrm{T})(30 \mathrm{mU} / \mathrm{ml})$ & $101.7 \pm 7.1^{*}$ \\
Tryptase $(\mathrm{T})(60 \mathrm{mU} / \mathrm{ml})$ & $68.2 \pm 3.6^{*}$ \\
Tryptase $(\mathrm{T})\left(120 \mathrm{mU} / \mathrm{ml}^{\ddagger}\right)$ & $45.6 \pm 3.9^{*}$ \\
T $15+$ leupeptin & $55.3 \pm 6.2$ \\
T $30+$ leupeptin & $55.0 \pm 7.3^{\dagger}$ \\
T $60+$ leupeptin & $58.9 \pm 4.4^{\dagger}$ \\
T $120+$ leupeptin & $49.3 \pm 6.9$ \\
TGF- $\beta(10 \mathrm{ng} / \mathrm{ml})$ & $132.0 \pm 10.6^{*}$ \\
Heparin $(10 \mu \mathrm{g} / \mathrm{ml})^{\ddagger}$ & $45.4 \pm 5.5$ \\
\end{tabular}

All values are means \pm SEM of three to four experiments except where indicated ( $¥)$ for certain experiments with two experiments. ${ }^{*} P<0.05$ compared to untreated controls. ${ }^{\dagger} P<0.05$ compared with active tryptase. 
A

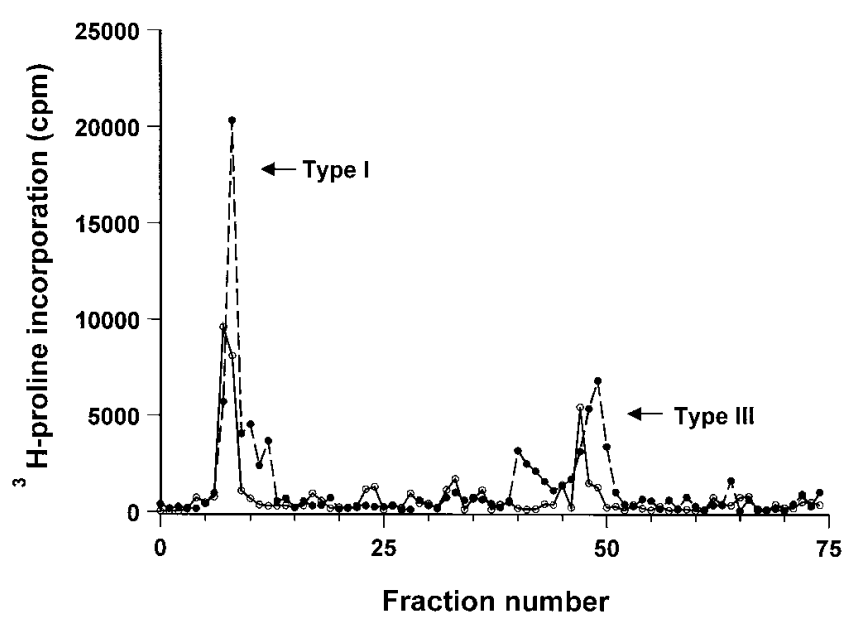

B

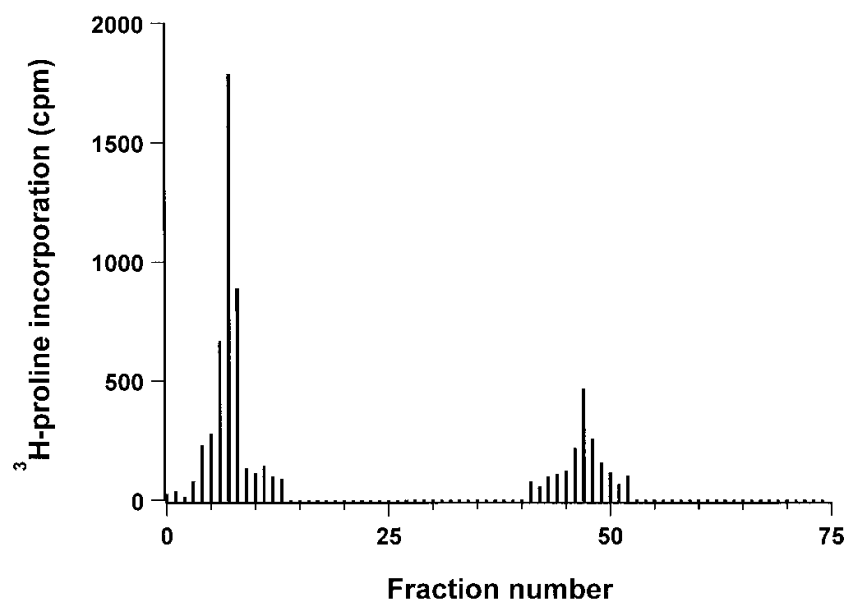

Figure 6. Separation of procollagens by DE 52 ion-exchange chromatography. $(A)\left[{ }^{3} \mathrm{H}\right]$ proline incorporation in fractions of supernatants from control, untreated cells $(\bigcirc)$, or from cells that were treated with $25 \mathrm{mU} / \mathrm{ml}$ tryptase (containing heparin) (-) in the presence of $\left[{ }^{3} \mathrm{H}\right]$ proline for $60 \mathrm{~h}$. (B) Collagenous protein in fractions.

Hydroxyproline content. The hydroxyproline content of supernatants was highest following incubation of cells with 30 $\mathrm{mU} / \mathrm{ml}$ tryptase, and smaller increases were observed at 60 and $120 \mathrm{mU} / \mathrm{ml}$ tryptase (Table II), consistent with the results obtained by measuring $\left[{ }^{3} \mathrm{H}\right]$ proline incorporation. Exposure of cells to tryptase in the presence of leupeptin decreased the hydroxyproline content of the supernatants. A fourfold increase in hydroxyproline was measured in the supernatants of cells treated with $10 \mathrm{ng} / \mathrm{ml}$ TGF- $\beta$, while no significant effect was found with $10 \mu \mathrm{g} / \mathrm{ml}$ of heparin alone.

Chromatographic separation of collagens. Ion-exchange chromatography of supernatants from control or tryptase-treated cells cultured in the presence of $\left[{ }^{3} \mathrm{H}\right]$ proline resolved two major peaks of radioactivity (Fig. $6 \mathrm{~A}$ ), and both contained collagenous protein (Fig. $6 B$ ) based on assay of the fractions for collagen as outlined above. The $\alpha$-chain composition of the collagenous protein peaks was determined by SDS-PAGE and autoradiography. The protein from peak 1 consisted of pro- $\alpha 1$

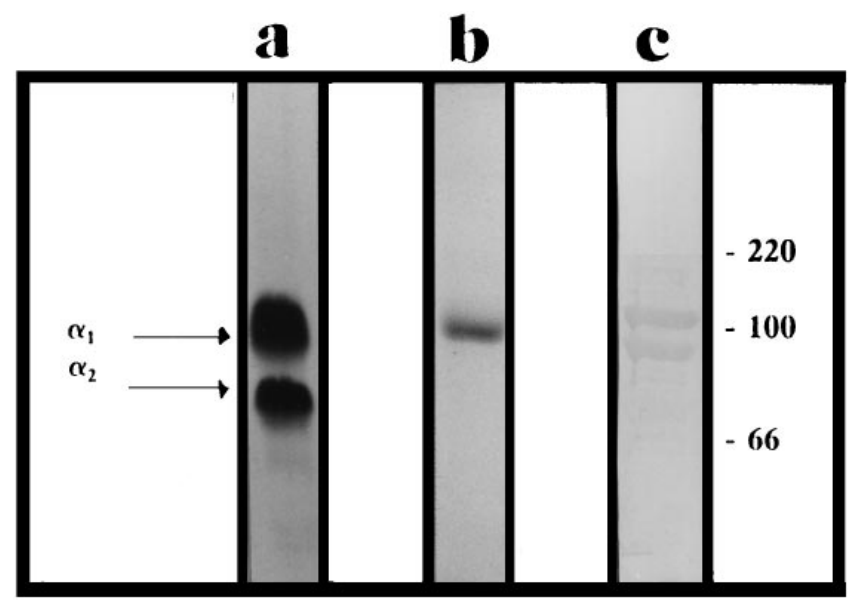

Figure 7. $\alpha$-Chain composition of collagenous proteins eluted from the DE52 column. SDS-PAGE and autoradiography of pooled fractions from $(a)$ peak 1 and $(b)$ peak 2. (c) Immunoblot of peak 1 with anti-type I collagen antibody. The right margin indicates $\mathrm{M}_{\mathrm{r}} \times 10^{-3}$.

and pro- $\alpha 2$ chains, which according to band intensity appeared to be present in a ratio of approximately $2: 1$ while peak 2 migrated as a single band (Fig. 7 a). On the basis of the $\alpha$ chain composition, peak 1 was determined to be procollagen type I, and peak 2 to be procollagen type III. Tryptase treatment of fibroblasts increased synthesis of procollagen type I by approximately twofold, while little change was observed with type III collagen (Fig. $6 \mathrm{~A}$ ). The identity of type I collagen was also confirmed by immunoblotting with an antibody to type I collagen (Fig. $7 c$ ).

Collagenolytic assay. The possibility was investigated that tryptase may impair collagen degradation by decreasing collagenase production, thus enhancing collagen synthesis indirectly. There was a twofold increase in total collagenolytic activity measured in supernatants of fibroblasts exposed to 25 $\mathrm{mU} / \mathrm{ml}$ tryptase compared with that from untreated cells (Table III). Collagenolytic activity was abolished in the presence of the calcium chelating agent EDTA (data not shown). These findings indicate that the enhanced collagen synthesis after exposure to tryptase is not an indirect consequence of decreased collagenolytic activity.

Table III. Collagenolytic Activity in Supernatants from Untreated Cells or from Cells Treated with $25 \mathrm{mU} / \mathrm{ml}$ Tryptase in the Presence or Absence of $50 \mu \mathrm{g} / \mathrm{ml}$ Leupeptin

\begin{tabular}{ll}
\hline \multicolumn{1}{c}{ Treatment } & $\%$ digestion \\
\hline Untreated controls & $19.2 \pm 2.9$ \\
Tryptase & $28.1 \pm 2.7^{*}$ \\
Tryptase + leupeptin & $21.0 \pm 2.3$ \\
Bacterial collagenase $^{\ddagger}$ & $85.0 \pm 4.7^{*}$
\end{tabular}

Purified bacterial collagenase $(10 \mu \mathrm{g} / \mathrm{ml})$ was used as a positive control. Values are means \pm SEM of values from three experiments, except those marked ${ }^{\ddagger}$, which are from two experiments. $* P<0.05$ compared with untreated controls. 


\section{Discussion}

We have confirmed that tryptase can act as a growth factor for human fibroblasts, and have demonstrated for the first time that this major product of mast cell activation can stimulate the synthesis of collagen. These findings provide compelling evidence for an important association between mast cells and fibroblasts in fibrotic disease, and are in accord with observations of high levels of tryptase and other mast cell products in the biological fluids of patients with conditions that may be characterized by abnormal collagen deposition (4-6). Tryptase isolated to high purity by two different means elicited similar effects on the fibroblasts, and the identity of the stimulus as tryptase was further confirmed by the observation that the protease inhibitors leupeptin and benzamidine hydrochloride markedly reduced cell responses.

Tryptase stimulated a 2.5 -fold increase in collagen synthesis in lung fibroblasts $48 \mathrm{~h}$ after addition to cell cultures. The mechanism did not appear to be dependent on TGF- $\beta$, as incubation of the cells with tryptase in the presence of a neutralizing antibody to TGF- $\beta$ failed to alter the response to tryptase. Tryptase appears to have a differential effect on the synthesis of collagen, with its actions directed predominantly towards the synthesis of type I collagen. The synthesis of type III collagen, the other major type secreted by lung fibroblasts (45), did not appear to be affected by tryptase. The optimum concentrations of tryptase (equivalent to final concentrations of $\sim 1-2 \mu \mathrm{g} / \mathrm{ml}$ ) required to elicit the increase represent concentrations of tryptase that are likely to be achieved in vivo. Tryptase concentrations as high as $13 \mathrm{ng} / \mathrm{ml}$ have been measured in BAL fluid from asthmatics (46), and since levels of tryptase may be diluted more than 100-fold in BAL fluid, these concentrations should be sufficient to trigger the responses observed.

Collagen types I, II, III, V, and XI, representing the major interstitial collagens, are composed of one to three $\alpha$-chains, each of 95-100 kD molecular weight, associated to form a single triple helix structure (47). Type I collagen has an asymmetric heterotrimeric configuration composed of $\alpha 1$ and $\alpha 2$ chains in a stoichiometric proportion of $2: 1$, giving rise to the chain composition $\left(\alpha_{1}[\mathrm{I}]_{2}, \alpha_{2}[\mathrm{I}]\right)$ (47) while type III collagen, a homotrimer of three $\alpha 1$ chains has the designation $\left[\alpha_{1}(\mathrm{I})\right]_{3}$. The $\alpha 1$ and $\alpha 2$ chains of type I collagen migrate at slightly different rates under reducing conditions (43). The collagen stimulated by tryptase treatment was identified as type I on the basis of the $\alpha$ chain composition, and by immunoblotting with a specific antibody to type I collagen. The collagens form an integral part of the extracellular matrix, and the amount of collagen deposited in the lung is tightly regulated to ensure a strict balance between biosynthesis and degradation. An inappropriate control of this balance can lead to enhanced collagen deposition resulting in fibrosis. It is now recognized that any alterations in either the amounts of collagen as reported in acute respiratory distress syndrome (48), cryptogenic fibrosing alveolitis (49), sarcoidosis (50), or indeed the type of collagens, may contribute to cellular abnormalities in the lung. The normal human lung is composed of $65 \%$ type I and $30 \%$ type III collagen. A specific increase in the amount of type I collagen, with a concomitant decrease in type III, has been reported in idiopathic chronic pulmonary fibrosis (51), and in fibrosis associated with atherosclerosis (52) and liver cirrhosis (53). In general, compliant tissues have a low ratio of type I to type III col- lagen, while less compliant tissues such as that found in pulmonary fibrosis, have a higher ratio. There is evidence of mast cell activation near areas of increased fibroblast activity, suggesting mast cell involvement in the fibrotic process. Stimulation of type I collagen synthesis by tryptase would be in keeping with this observation. Cells derived from animals which have been treated with bleomycin to induce experimental fibrosis show a similar increase in the synthesis of type I collagen (40). This result is in agreement with changes observed in fibroblasts treated with bleomycin in vitro $(38,40)$.

The preferential stimulation of type I collagen synthesis by tryptase also suggests a role for tryptase in chronic fibrosis resulting from ongoing mast cell activation since type I collagen has been reported to be found preferentially in established fibrotic lesions, while type III collagen is characteristic of early fibrosis (45). Collagen synthesis stimulated by tryptase cannot be attributed to decreased collagenase production by the cells, as there was a twofold increase in collagenase activity in the culture medium after tryptase exposure. Thus, the increase in collagen detected after tryptase treatment must reflect an increase in the net biosynthetic rate of type I collagen. Release of collagenase activity concomitant with the deposition of new collagen could be an important process in matrix remodeling. Increased collagenolytic activity has been reported in BAL fluid from patients with diffuse interstitial fibrosis (DIF) (54) where an elevation in tryptase levels has also been reported $(4,55)$.

An increase in the fibroblast cell population as well as an increase in collagen synthesis are key features of fibrotic disease. Our observation that tryptase can stimulate both an increase in cell numbers and a fivefold increase in DNA synthesis $32 \mathrm{~h}$ after addition to cultures of the MRC-5 fibroblast line is in keeping with reports from other investigators. Dog tryptase has been found to stimulate a 2- to 3-fold increase in bromodeoxyuridine uptake in cultured dog tracheal smooth muscle cells (28), while an increase of 2.5 -fold in cell numbers has been reported with human lung tryptase added to human lung fibroblasts (27). The ability of tryptase to stimulate fibroblast proliferation and collagen synthesis appears to be mediated via the catalytic site. This suggests that $(a)$ a proteolytic event is required to initiate the intracellular signalling pathway, or $(b)$ tryptase could interact with a putative receptor at a point close to the catalytic site. The actions of another serine protease (thrombin) on cells appears to be mediated via cleavage of a tethered ligand in a specific receptor (56). A specific receptor for tryptase remains to be identified, but the action of tryptase on fibroblasts does not appear to be mediated via the thrombin receptor since it has been shown that tryptase does not affect stimulation of DNA synthesis by the synthetic thrombin receptor peptide Ser-Phe-Phe-Leu-Arg-Asn-Pro (SFFLRNP) (57). The identification of the structurally related proteinase-activated receptor-2 (PAR-2), which can be activated by trypsin (58), has reinforced the concept that proteases can bind to specific receptors and play pivotal roles as mediators of cellular events.

Tryptase has been reported to have both direct and indirect effects on connective tissue catabolism. This enzyme can degrade intact type VI collagen microfibrils (59), inactivate fibrinogen (23), and can activate latent collagenase by a process dependent on the activation of prostromelysin (24). Our data provides evidence for a new role for mast cell tryptase in fibrogenesis. Tryptase released during mast cell degranulation could provide a stimulus both for fibroblast proliferation and 
collagen synthesis, resulting in increased collagen deposition in fibrotic lesions. The overall increase in collagen production stimulated by tryptase may lead to mechanical impairment in the fibrotic lung, while the selective increase in type I collagen could contribute to the overall rigidity. It has recently been reported that inhibitors of tryptase may be efficacious in controlling acute allergic reactions in sheep airways (60). The ability of tryptase to participate in processes of matrix remodelling suggests that this new class of drugs may prove beneficial in chronic conditions associated with mast cell activation.

\section{Acknowledgment}

This work was funded by a grant from the Medical Research Council.

\section{References}

1. Kovacs, E.J. 1991. Fibrogenic cytokines: The role of immune mediators in the development of scar tissue. Immunol. Today. 12:17-23.

2. Kawanami, O., V.J. Ferrans, J.D. Fulmer, and R.G. Crystal. 1979. Ultrastructure of pulmonary mast cells in patients with fibrotic lung disorders. Lab. Invest. 40:717-734.

3. Heard, B., A. Dewar, and B. Corrin. 1992. Apposition of fibroblasts to mast cells and lymphocytes in normal human lung and in cryptogenic fibrosing alveolitis. Ultrastructure and cell perimeter measurements. J. Pathol. 166:303310 .

4. Walls, A.F., A.R. Bennet, R.C. Godfrey, S.T. Holgate, and M.K. Church. 1991. Mast cell tryptase and histamine concentrations in bronchoalveolar lavage fluid from patients with interstitial lung disease. Clin. Sci. (Lond.). 81:183188.

5. Casale, T.B., S. Trapp, B. Zehr, and G.W. Hunninghake. 1988. Bronchoalveolar lavage fluid histamine levels in interstitial lung disease. Am. Rev. Respir. Dis. 138:1604-1608.

6. Ruoss, S.J., and G.H. Caughey. 1995. Mast cells, basophils, and eosinophils in the evolution of pulmonary fibrosis. In Pulmonary Fibrosis. S.H. Phan, and R.S. Thrall, editors. Marcel Dekker, Inc., New York. 445-480.

7. Atkins, F.M. 1987. Mast cells and fibrosis. Arch. Dermatol. 123:191-193.

8. Levi-Schaffer, F., and E. Rubinchik. 1995. Activated mast cells are fibrogenic for 3T3 fibroblasts. J. Invest. Dermatol. 104:999-1003.

9. Atkins, F.M., M.M. Friedman, V. Pillarisetti, P.V. Subba Rao, and D. Metcalfe. 1985. Interaction between mast cells, fibroblasts and connective tissue components. Int. Arch. Allergy Appl. Immunol. 77:96-102.

10. Subba-Rao, P.V., M.M. Friedman, F.M. Atkins, and D.D. Metcalfe. 1983. Phagocytosis of mast cell granules by cultured fibroblasts. J. Immunol. 130:341-349.

11. Russell, J.D., S.B. Russell, and K.M. Trupin. 1977. The effect of histamine on the growth of cultured fibroblasts from normal and keloid tissue. $J$. Cell Physiol. 93:389-394.

12. Hatamochi, A., K. Kujiwara, and H. Ueki. 1985. Effects of histamine on collagen synthesis by cultured fibroblasts derived from guinea pig skin. Arch. Dermatol. Res. 277:60-64.

13. Yayon, A., M. Klagsbrun, J.D. Esko, P. Leder, and D.M. Ornitz. 1991. Cell surface, heparin-like molecules are required for binding of basic fibroblast growth factor to its high affinity receptor. Cell. 64:841-848.

14. Mueller, S.N., K.A. Thomas, J. DiSalvo, and E.M. Levine. 1989. Stabilization by heparin of acidic fibroblast growth factor mitogenicity for human endothelial cells in vitro. J. Cell Physiol. 140:439-448.

15. Saksela, O., D. Moscatelli, A. Sommer, and D.B. Rifkin. 1988. Endothelial cell-derived heparan sulphate binds basic fibroblast growth factor and protects it from proteolytic degradation. J. Cell Biol. 107:743-751.

16. Gospodarowicz, D., and J. Chen. 1986. Heparin protects acidic and basic fibroblast growth factor from inactivation. J. Cell Physiol. 128:475-484.

17. Bradding, P., A.F. Walls, and M.K. Church. 1995. Mast cells and basophils: Their role in initiating and maintaining inflammatory responses. In Immunology of the Respiratory System. S.T. Holgate, editor. Academic Press, London. 53-84.

18. Schwartz, L.B. 1990. Tryptase from human mast cells: biochemistry, biology, and clinical utility. In Neutral Proteases of Mast Cells. L. B. Schwartz, editor. Karger, Basel, Switzerland. 90-113.

19. Schwartz, L.B., and T.R. Bradford. 1986. Regulation of tryptase from human lung mast cells by heparin: stabilisation of the active tetramer. J. Biol. Chem. 261:7372-7379.

20. Schwartz, L.B., A.A. Irani, K. Roller, C. Castells, and N.M. Schechter. 1987. Quantitation of histamine, tryptase and chymase in dispersed human T and TC mast cells. J. Immunol. 138:2611-2615.

21. Walls, A.F., S.D. Brain, A. Desai, P.J. Jose, E. Hawkings, M.K. Church, and T.J. Williams. 1992. Human mast cell tryptase attenuates the vasodilator activity of calcitonin gene-related peptide. Biochem Pharmacol. 43:1243-1248.

22. Tam, E.K., and G.H. Caughey. 1990. Degradation of airway neuropeptides by human lung tryptase. Am. Rev. Respir. Cell Mol. Biol. 3:27-32.

23. Schwartz, L.B., T.R. Bradford, B.H. Littman, and B.U. Wintroub. 1985. The fibrinogenolytic activity of purified tryptase from human lung mast cells. $J$. Immunol. 135:2762-2767.

24. Gruber, B.L., M.J. Marchese, K. Suzuki, L.B. Schwartz, Y. Okada, H Nagase, and N.S. Ramamurthy. 1989. Synovial procollagenase activation by human mast cell tryptase. Dependence upon matrix metalloproteinase 3 activation. J. Clin. Invest. 84:1657-1662.

25. Stack, M.S., and D.A. Johnson. 1994. Human mast cell tryptase activates single-chain urinary type plasminogen activator (pro-urokinase). J. Biol. Chem. 269:9416-9419.

26. Lohi, J., I. Harvima, and J. Keski-Oja. 1992. Pericellular substrates of human mast cell tryptase: 72,000 dalton gelatinase and fibronectin. J. Cell. Biochem. 50:337-349.

27. Ruoss, S.J., T. Hartman, and G.H. Caughey. 1991. Mast cell tryptase is a mitogen for cultured fibroblasts. J. Clin. Invest. 88:493-499.

28. Brown, J.K., C.L. Tyler, C.A. Jones, S.J. Ruoss, T. Hartman, and G.H. Caughey. 1995. Tryptase, the dominant secretory granular protein in human mast cells, is a potent mitogen for cultured dog tracheal smooth muscle cells. Am. J. Respir. Cell Mol. Biol. 13:227-236.

29. Cairns, J.A., and A.F. Walls. 1996. Mast cell tryptase is a mitogen for epithelial cells. Stimulation of IL-8 production and intercellular adhesion molecule-1 expression. J. Immunol. 156:275-283.

30. Walls, A.F., S. He, M.G. Buckley, K.-S., Jung, S.T. Holgate, J.K. Shute, and J.A. Cairns. 1995. Granulocyte recruitment by human mast cell tryptase. Int. Arch. Allergy Immunol. 107:372-373.

31. Paz, M.A., and P.M. Gallop. 1975. Collagen synthesised and modified by aging fibroblasts in culture. In Vitro (Rockville). 11:302-312.

32. Schwartz, L.B., R.A. Lewis, and K.F. Austen. 1981. Tryptase from human pulmonary mast cells. Purification and characterisation. J. Biol. Chem. 256: 11939-11943.

33. Laemmli, U.K. 1970. Cleavage of structural proteins during the assembly of the head of bacteriophage T4. Nature (Lond.). 227:680-685.

34. Walls, A.F., A.R. Bennet, H.M. McBride, M.J. Glennie, S.T. Holgate, and M.K. Church. 1990. Production and characterisation of monoclonal antibodies specific for human mast cell tryptase. Clin. Exp. Allergy. 20:581-589.

35. Postlewaite, A.E., G.N. Smith, C.L. Mainardi, J.M. Seyer, and A.H Kang. 1984. Lymphocyte stimulation of fibroblast function in vitro: stimulation and inhibition of collagen production by different effector molecules. J. Immunol. 132:2470-2477.

36. Peterkofsky, B., and Diegelmann. 1970. Use of a mixture of proteinasefree collagenases for the specific assay of radioactive collagen in the presence of other proteins. Biochemistry. 10:988-994.

37. Juva, K., and D.J. Prockop. 1966. Modified procedure for the assay of H3- or C14-labelled hydroxyproline. Anal. Biochem. 15:77-83.

38. Clark, J.G., B.C. Starcher, and J. Uitto. 1980. Bleomycin-induced synthesis of type I procollagen by human lung and skin fibroblasts in culture. Biochim. Biophys. Acta. 631:359-370.

39. Sykes, B.C. 1976. The separation of two soft tissue collagens by covalent chromatography. FEBS Lett. 61:180-185.

40. Phan, S.H., J. Varani, and D. Smith. 1985. Rat lung fibroblast collagen metabolism in bleomycin-induced pulmonary fibrosis. J. Clin. Invest. 76:241247.

41. Madri, J.A., and H. Furthmayr. 1980. Collagen polymorphism in the lung. An immunochemical study of pulmonary fibrosis. Human Pathol. 11:353366.

42. Neville, D.M. 1971. Molecular weight determination of protein dodecyl sulphate complexes by gel electrophoresis in a discontinuous buffer system. $J$. Biol. Chem. 246:6328-6334.

43. Furthmayr, H., and R. Timpl. 1971. Characterisation of collagen peptides by sodium dodecyl sulphate polyacrylamide electrophoresis. Anal. Biochem. 41:510-516.

44. Deleted in proof.

45. Bateman, E., M. Turner-Warwick, and B.C. Adelmann-Grill. 1981. Immunohistochemical study of collagen types in human fetal lung and fibrotic lung disease. Thorax. 36:645-653.

46. Broide, D.H., G.J. Gleich, A.J. Cuomo, D.A. Coburn, E.C. Federman, L.B. Schwartz, and S.I. Wasserman. 1991. Evidence of ongoing mast cell and eosinophil degranulation in symptomatic asthma airway. J. Allergy Clin. Immunol. 88:637-641.

47. Timpl, R. 1977. Immunological studies on collagen. In Biochemistry of Collagens. G.N. Ramachandran and A.H. Reddi, editors. New York Academic Press. 319-326.

48. Zapol, W.M., R.L. Trelstad, J.W. Coffey, I. Tsai, and R.A. Salvador 1979. Pulmonary fibrosis in severe acute respiratory failure. Am. Rev. Respir. Dis. 119:547-554.

49. Selman, M., M. Montano, C. Ramos, and R. Chapale. 1986. Concentration, biosynthesis and degradation of collagen in idiopathic pulmonary fibrosis. Thorax. 41:355-359. 
50. Bjermer, L., A. Engstrom-Laurent, M. Thunnel, and R. Hallgren. 1987. The mast cell and signs of pulmonary fibroblast activation in sarcoidosis. Int. Arch. Allergy Appl. Immunol. 82:298-301.

51. Seyer, J.M., E.T. Hutcheson, and A.H. Kang. 1976. Collagen polymorphism in idiopathic pulmonary fibrosis. J. Clin. Invest. 57:1498-1507.

52. McCullagh, K.A. 1975. Collagen characterisation and cell transformation in human atherosclerosis. Nature (Lond.). 258:73-75.

53. Seyer, J.M., E.T. Hutcheson, and A.H. Kang. 1977. Collagen polymorphism in normal and cirrhotic liver. J. Clin. Invest. 59:241-244.

54. Gadek, J.E., J.A. Kelman, G. Fells, S.T. Weinberger, A.L. Horwitz, H.Y. Reynolds, J.D. Fulmer, and R.G. Crystal. 1979. Collagenase in the lower respiratory tract of patients with idiopathic pulmonary fibrosis. N. Engl. J. Med. 301:737-742.

55. Hunt, L.W., T.V. Colby, D.A. Weiler, S. Sur, and J.H. Butterfield. 1992. Immunofluorescent staining for mast cells in idiopathic pulmonary fibrosis: quantification and evidence for extracellular release of mast cell tryptase. Mayo Clin. Proc. 67:941-948.
56. Vu, T.K., D.T. Huang, V.I. Wheaton, and S.R. Coughlin. 1991. Molecular cloning of a functional thrombin receptor reveals a novel proteolytic mechanism of receptor activation. Cell. 64:1057-1060.

57. Hartmann, T., S.J. Ruoss, and G.H. Caughey. 1994. Modulation of thrombin and thrombin receptor peptide mitogenicity by human lung mast cell tryptase. Am. J. Physiol. 267:113-117.

58. Nystedt, S., K. Emilsson, A.K. Larsson, B. Strombeck, and J. Sundelin. 1995. Molecular cloning and functional expression of the gene encoding the human proteinase-activated receptor 2. Eur. J. Biochem. 232:84-89.

59. Kielty, C.M., M. Trojanowska, and A.E. Smith. 1991. Catabolism of intact type VI collagen microfibrils: susceptibility to degradation by serine proteinases. Biochem. Biophys. Res. Commun. 191:1230-1236.

60. Clark, J.M., W.M. Abraham, C.E. Fishman, R. Forteza, A. Ahmed, A Cortes, R.L. Warne, W.R. Moore, and R.D. Tanaka. 1995. Tryptase inhibitors block allergen-induced airway and inflammatory responses in allergic sheep. Am. J. Respir. Crit. Care Med. 152:2076-2083. 